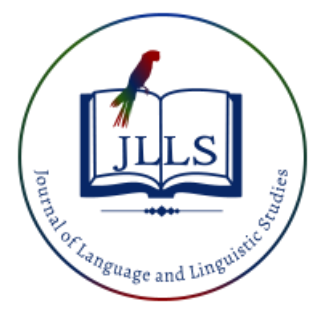

Available online at www.jlls.org

JOURNAL OF LANGUAGE

AND LINGUISTIC STUDIES

ISSN: $1305-578 \mathrm{X}$

Journal of Language and Linguistic Studies, 17(2), 828-841; 2021

\title{
An analysis and insight into the effectiveness of scaffolding: EFL instructors'/teachers' perceptions and attitudes
}

\author{
Abdelmagid Abdelrahman Awadelkarim ${ }^{1}$ a iD \\ ${ }^{a}$ Majmaah University, Saudi Arabia
}

\section{APA Citation:}

Awadelkarim, A. (2021). An analysis and insight into the effectiveness of scaffolding: EFL instructors'/teachers' perceptions and attitudes. Journal of Language and Linguistic Studies, 17(2), 828-841. Doi: 10.52462/j1ls.58

Submission Date:08/03/2021

Acceptance Date:15/05/2021

\begin{abstract}
This study examines the effectiveness of scaffolding in the context of Majmaah University EFL. It does so by exploring the attitudes and perceptions of a randomly selected group of (30) EFL instructors of various backgrounds and degrees. Theoretically, it is informed by a medley of relevant theories and approaches Vygotsky's Sociocultural Theory of Learning, Bakhtin's Dialogism and Habermas' Communicative Rationality. Methodologically, a combination of a questionnaire (23 participants) and focus group discussions (FGD) (7 participants) were employed to collect the data and then analyze it using a pertinent tool for each instrument. The three questions the paper set out to answer were: 1) what are the perceptions and attitudes of Majmaah University EFL teachers towards scaffolding? 2) To what extent are they aware of scaffolding in teaching? 3) What is their attitude for practicing scaffolding in pedagogical contexts?. Even though the analysis largely revealed that the participants practiced scaffolding in some way or the other and that their attitudes and perceptions regarding practical pedagogical scaffolding were exceedingly positive, there were, nonetheless, interesting complexities unveiled all along. Contrary to the seemingly participants' perception of a strong belief of their knowledge of the principles and approaches underlying scaffolding, profound analysis suggests that they, in fact, lack adequate relevant knowledge/competence. The participants appeared less confident of their beliefs when it comes to practical and pedagogical scaffolding. The major contribution of this paper lies in the apparent gap it fills with its narrow focus on the instructors' attitudes and perceptions alongside its innovative employment of focus group discussion (FGD) as an effective research tool.
\end{abstract}

Keywords: Scaffolding; Perceptions; Attitudes; ZPD; Dialogism; Focus group discussion (FGD).

\section{Introduction}

The analogy of scaffolding originally comes from the temporary structure that is raised for the construction or repair of buildings. This metaphor is applied to adolescent students' learning process which involves a gradual support structure to be raised and laid off to achieve the goal of autonomous learning in a sociocultural environment. Epistemologically, scaffolding draws on a variety of philosophical, psychological, educational and sociocultural sources (The Socratic Method of the dialogic nature of truth, Vygotsky's Sociocultural Theory of the mind, Bakhtin's Dialogism along with

\footnotetext{
${ }^{1}$ Corresponding author.

E-mail address: a.elkarim@mu.edu.sa
} 
his related concepts of heteroglossia and polyphony - multivoices -Habermas' Communicative Rationality, etc.). However, it is the Dialogism of Bakhtin and Vygotsky's Zone of Proximal Development (ZPD) that appears to have particularly influenced and enriched further scaffolding.

Vygotsky's Sociocultural Theory of learning would presumably bear all the contours of scaffolding essential for English language learners. This theory envisages learning as a process that leads to development wherein language is the key tool to represent thought. However, learning cannot take place in isolation and hence adult mediation occupies a central position in the process. To articulate the space in which learning occurs, Vygotsky introduced the Zone of Proximal Development (ZPD) - "a construct that outlines the distance between the level of actual development as an independent learner and the level of the potential development achieved using solving problems with the support of an adult guide and facilitator or in collaboration with peers who are comparatively more capable", (Vygotsky, 1978: 86) (for an intensive critical review of the influence of Vygostky on SLA modern research see Pathan, et al. 2018). Later, Bakhtin's (1981) (who was also a contemporary of Vygotsky's but outlived him) inspired by Vygotsky's Sociocultural Theory of learning, propounded the philosophy of dialogism arguing it is ingrained in human consciousness, and the internalization of the same occurs utilizing interactive activities involving thoughts and languages (Teo, 2019). As scaffolds, dialogic and collaborative interactions support in extending students' learning. The key takeaway of Bakhtin's theory is his emphasis on the dialogic nature of the truth and of learning.

Dialogism and (ZPD) have particularly informed the recent surge in scaffolding approaches in the context of EFL. These approaches may be psycholinguistic, sociolinguistic, or pedagogical (Yu, 2004). Scaffolding in the sociolinguistics context was posited by Vygotsky (1978) to designate a sort of support extended by an expert to a novice epitomized by what he calls 'Zone of Proximal Development. In view of Vygotsky (1978), the achievement of learning, a novice can learn from an expert through a continuous process of scaffolding interaction. A teacher is commonly regarded as 'an expert,' for providing supports in the forms of scaffolds to an amateur learner (novice), just as novice mechanics often learn from older experienced ones.

Many more recent studies present 'an expert' as a person whose role is not merely confined to a classroom teacher, but learners can likewise provide scaffolding of some degree inside or outside classrooms. Indeed, students can provide invaluable assistance to their peers (see Donato, 1994; De Guerrero and Villamil, 2000; Ohta, 2001). Khamwan (2007) studied the effect of interactional strategy training on teacher-student interaction aiming to increase its classroom effectiveness and stressing that scaffolding is one such interactional strategy. Pertinently, Charttrakul (2009) argued that "scaffolding is very important for EFL young learners, particularly in Thai classroom situations where students rarely use L2 or English in their real-life" (p.14). Similarly, Nomnian (2002) called for more attention to promote teacher-student scaffolding interaction in the language classroom. According to Khamwan (2007), Thai academies feel familiar with the concept of classroom interaction between the teacher and students. Unfortunately, scaffolding interaction between students has received very little attention. Students are not familiar with scaffolding from their peers, and they are not trained to scaffold their peers alongside other factors such as not having enough time to interact during classes in many contexts. Not to speak of students, even some teachers are not well aware of the systematic scaffolding in EFL teaching and learning wherein a structure has to be raised and laid off gradually to attain the objective of autonomous learning. The amount of teaching support to be extended and withdrawn according to the learning styles, as well as levels of the students, is a very complex phenomenon in Vygotsky's ZPD and Halliday's model of language teaching (Hammond \& Gibbon, 2005). Classifications of scaffolding can differ across the literature depending on the objectives, questions and method of researchers. In a very recent classification, Tajeddin \& Kamali (2020: 329) have used a corpus-based method to identify four types of scaffolding: meta-scaffolding, linguistic scaffolding, 
affective scaffolding, and under-scaffolding along with a host of subcategories such as: "inter alia, meta-linguistic scaffolding, gestural scaffolding, resource providing, audiovisual organizers, reformulation, elicitation, echoing, and emotional scaffolding." Both the classification and the method used in Tajeddin and Kamali's study to elicit them have been innovative and of paramount importance, even though they may complicate the issue further.

The need for the current study at Majmaah University first came to the fore while holding a seminar on scaffolding for the professional development of EFL faculty members. Referring back to the context of the study the problem arose when different faculty members responsible for teaching EFL skill classes frankly admitted that they rarely consciously employ scaffolding techniques and strategies while teaching EFL classes. Particularly, newly recruited teachers and instructors showed even ignorance about the concept of scaffolding that basically deals with the construction of buildings. During the course of discussions, it occurred to us that the perceptions of EFL teachers need a thorough examination for the systematic implementation of appropriate scaffolds while teaching in the traditional classroom or online, necessitated particularly by the currently extraordinary situation created by Covid-19.

\subsection{Research questions}

In the light of all the above, this study aims to achieve its twofold goals: examining the perceptions of EFL teachers regarding scaffolding, on the other hand, and evaluating how conscious they are while implementing it in traditional as well as virtual classrooms. This will be sought via attempting to tackle the following questions:

1. What are the perceptions and attitudes of Majmaah University EFL teachers towards scaffolding?

2. To what extent are they aware of scaffolding in teaching?

3. What is their attitude for practicing scaffolding in pedagogical contexts?

\section{Review of the Literature}

An overview of previous studies reveals that myriads of studies have been conducted ever since the inception of the systematic use of scaffolding in the teaching and learning process. The pioneers of this theory Piaget (1979) and Vygotsky (1987) postulated that learning occurs when a support structure is built to bridge the gap between what a learner already knows and what has to be learned. In the EFL context, most of the studies were experimental and opted to investigate the effect of scaffolding strategies employed in the classroom, and simply and largely concluded that the results have been positive. Very few studies have been conducted exclusively on the perceptions of teachers and their consciousness of the implementation of scaffolding while teaching in the classroom. Very recently, Abdelshaheed, (2019) while evaluating functioning instructional scaffolding strategies at Majmaah University vehemently recommended further investigation into the processes of scaffolding the EFL instructors adhere to while teaching in the classroom. Previously, the studies predominantly focused on using scaffolding strategies to develop a particular communicative skill as witnessed in (Ahmadi \& Rozati, 2017), (Rezaee, Farahani \& Mubarak (2018), (Rababah \& Almwajeh, 2018) and (Azir, 2019) to mention but a few. Another recent study exclusively deals with a content language integrated learning ( $\mathrm{Li} \&$ Zhang, 2020), but without any focus on perceptions and the active awareness of employing befitting scaffold while teaching in the classroom. Few studies attempted to investigate the phenomenon from the perception lens. One study, investigated the significance of scaffolding with a particular reference to Zone of proximal development (ZPD) as perceived by L2 teachers (Yu, 2004). Although this article highlights the importance of appropriate perceptions and practice of scaffolding on the part of English teachers, it, however, seems to lack the essential measuring tools to make it 
valid and reliable. Nasr, Bagheri, Sadighi, and Rassaei (2018) ventured to investigate EFL teachers' perceptions relating to evaluation of learning in respect of scaffolding practices in their demographical context. As this study is confined to assessment for learning (AFL), it leaves an essential space for exploring general perceptions of EFL teachers purely in the scaffolding paradigm. The paper by Troudi and Zayani (2020) demonstrates that even scaffolding is imperative for EFL teachers in order to enhance their knowledge by reading in accordance with a theoretical framework for better off delivery to the students in the long run.

Scaffolding has also been probed into from the point of view of learner's perception. Purnomo and Yuyun (2019) tried to explore the perception of the learners about how effective direct transmission and scaffolding were in the EFL classroom. This study was conducted by means of semi-structured interviews and pre-posttest tools. A similar study would undoubtedly be useful for exploring the attitudes and perceptions of EFL teachers as well.

Other researchers tried to examine the technological dimensions of scaffolding from the EFL learners' point of view. For instance, Mansouri and Mashhadi (2019), in their experimental study investigated the "effect of peer and teacher scaffolding employing a process-approach in technologyladen atmosphere exclusively for learning vocabulary". The focus of another study was the undergraduate engineering students whose general academic listening skills were evaluated in relation to the scaffolding strategies the instructors used when teaching them. In the conclusive remarks it was stated that further investigation is required in different courses of technical English for various departments, and that "in another research, instructors can be interviewed to elicit their opinions and approaches regarding the role of scaffolding in communicative skills with a special emphasis on listening skills" (Taghizadeh \& Saadatju, 2020). Muhammad (2020) also delves into scaffolding but confining it to online tasks for the sake of enhancing the critical writing skills of secondary school students. As a pre-post test study, it also revolved around the students rather than teachers' beliefs and perceptions about scaffolding. Nevertheless, in the recommendations for future research, it was suggested to examine scaffolding as a tool of developing language skills in general rather than writing alone.

Then, Krashen's input hypothesis (i+1) is another instance of challenging scaffolding in which "input + one" means that the comprehensible input should be one step higher than the current level of the linguistic competence (or multi-competence for that matter) of the learner. Even the affective filter (a milestone in Krashen's theory) which aims to remove the blockage in the way of comprehensive input would seem to need appropriate scaffolds (Krashen, 1988). These two hypotheses emphasize that teachers should be well aware of the "correct scaffolds" in facilitating the process of language learning and keeping the affective filter as low as possible for uninterrupted language acquisition (Aguilar, 2020). Similarly, Gunawardena (2019) who believes in "developing effective pedagogical frameworks for scaffolding thinking" calls upon the teachers to be aware of the scaffolds themselves and then try to help learners to develop their own critical creative thinking skills.

Scaffolding was seen as an integral part of teachers' professional development programs. A study conducted in the context of SWOT quadrant (strengths, weaknesses, opportunities and threats) to evaluate the development of ELT teachers' professionalism by reflecting on their roles as scaffolders laid stress upon "reflective training in the company and guidance of experts" till the time they become autonomous in visualizing and implementing appropriate scaffolds (Rachmajanti, Sulistyo \& Suharyadi, 2019).

Hence, there appears to be a clear gap for exploring the EFL teachers' attitude and perceptions exclusively for scaffolding and its implementation in the teaching process. 


\section{Methodology}

To achieve the objectives and to address the research questions, the study in hand opted for a mixed-method as a research design that allowed the integration of qualitative and quantitative methods (Creswell \& Clerk, 2007). A questionnaire and Focused Group Discussion (FGD) were found to be appropriate research tools in the pursuance of Leung's (2015) proposition of a pedagogical triangulation of the target data for validation and enrichment. The selected method and instruments paved the way for a better deliverance of qualitative and quantitative data for examining the attitude and perceptions of EFL teachers about scaffolding in a Saudi Arabian teaching context.

\subsection{Instruments}

As already mentioned, two research tools, i.e., a questionnaire and Focused Group Discussion (FGD) were used to probe the problem.

\subsubsection{Questionnaire:}

Containing three parts: (i) Knowledge and awareness of scaffolding (ii) Teachers' beliefs and perceptions (iii) Practices. In all, there were 15 items to be responded on a five-point Likert scale that ranged from "Strongly Agree" to "Strongly Disagree". This questionnaire for measuring teachers' attitudes and perceptions was adapted from Wozney and Abrami's (2006) and modified to suit the Saudi EFL context. Five veteran researchers as well as senior faculty members with ample teaching experience in Saudi universities were engaged in vetting and validating the contents of the questionnaire. After revision in view of the feedback from several referees, the questionnaire was transformed into a Google form which is a free software allowing the researchers to get as many responses as possible. It is time-saving as the link can be shared on social media like WhatsApp and Messenger. To make it more reliable, every participant was asked to mention his or her email. Twenty-three responses were received. First, these were presented on an Excel sheet and then imported to SPSS 22.0 for coding into tables. Cronbach's Alpha showed the reliability of the three sections as (0.86: 0.83 and 0.79$)$.

\subsubsection{Focused Group Discussion (FGD):}

In mixed methods, the use of FGD does not merely complement data rather it offers a unique opportunity to have a holistic insight into the problem or phenomenon under investigation (Caillaud \& Flick, 2017). The participants were the EFL faculty members who attended the seminars on scaffolding as well. The discussions were held during and after two seminars on Scaffolding.

\subsection{Participants}

The participants of this study comprised 23 EFL teachers (5 female and 18 male) mainly from various English Departments of Majmaah University. The Google-formatted questionnaire was sent to them through email and WhatsApp. The breakup on the basis of qualifications came to be: $8.7 \%$ Ph.Ds., 52.2\% Masters and 38.1\% Bachelors. The majority of them bore certification of CELTA, DELTA, TESOL, or TEFL, also had an average EFL teaching experience of 8.5 years. Subsequently, around six of the faculty members voluntarily participated in Focused Group Discussion sessions. 


\section{Results and Discussion}

\subsection{Question-1: What are the general perceptions and attitudes of Majmaah University EFL} teachers towards scaffolding?

The first part of the survey dwelled upon measuring the degree of the knowledge and awareness of the participants about the fundamentals of the concept of scaffolding. It is worth noting that we are not unaware of the usually expected gaps between the responses and the reality of the situation. To minimize this, an effort was exerted to inform the participants about the significance of providing honest responses, on the one hand, and to incorporate the eye-opening questions into the general philosophy of the paper per se.

The participants' responses largely reveal that they do possess fundamental knowledge of the concept of scaffolding: around $47 \%$ agree strongly or moderately that they know some of the theoretical frameworks of scaffolding; $96 \%$ believe they are conscious of EFL classroom scaffolding strategies; more than $77 \%$ said they know what scaffolding constructs are; however only around $43 \%$ are certain that they know about Bakhtin's Dialogism and Vygotsky's ZPD (a meaningful response that will cast doubts over other related responses (esp., the assertions of the vast majority of the respondents that they know of the theoretical models of scaffolding and strategies!!); the latter applies also to the almost $74 \%$ who claim that they can build scaffolding plans both in and outside the classroom. This is because the lack of adequate knowledge of both Bakhtin's and Vygotsky's relevant theorizations render their other pertinent claims rather tenuous given the paramount importance of the contributions of these two scholars to the theory of scaffolding. Table 1 below reflects the statistic of the degree of knowledge and awareness of the EFL teachers about the theoretical aspects of scaffolding.

Table 1. Knowledge and Awareness of Scaffolding

\begin{tabular}{|c|c|c|c|c|c|c|c|}
\hline Item & $\begin{array}{l}\text { Strongly } \\
\text { Agree }\end{array}$ & Agree & Neutral & Disagree & $\begin{array}{l}\text { Strong } \\
\text { Disagree }\end{array}$ & Mean & SD \\
\hline $\begin{array}{l}\text { I am aware of some } \\
\text { theoretical } \\
\text { frameworks of } \\
\text { scaffolding (by for } \\
\text { example reading } \\
\text { some literature in the } \\
\text { field) }\end{array}$ & $30.4 \%$ & $43.5 \%$ & $8.7 \%$ & $4.3 \%$ & $13 \%$ & 2.3 & 1.39 \\
\hline $\begin{array}{l}\text { I am conscious of } \\
\text { scaffolding strategies } \\
\text { for EFL classrooms. }\end{array}$ & $21.7 \%$ & $47.8 \%$ & $13 \%$ & $13 \%$ & $4.3 \%$ & 2.4 & 1.34 \\
\hline $\begin{array}{l}\text { I know what } \\
\text { scaffolding constructs } \\
\text { are. }\end{array}$ & $17.4 \%$ & $60.9 \%$ & $13 \%$ & $4.3 \%$ & $4.3 \%$ & 2.2 & 1.04 \\
\hline $\begin{array}{l}\text { I know about } \\
\text { Bakhtin's philosophy } \\
\text { of dialogism and/or } \\
\text { Vygotsky's ZPD } \\
\text { model. }\end{array}$ & $8.7 \%$ & $34.8 \%$ & $34.8 \%$ & $13 \%$ & $8.7 \%$ & 2.9 & 1.27 \\
\hline
\end{tabular}




\begin{tabular}{llllllll}
\hline I know how to build & $8.7 \%$ & $65.2 \%$ & $8.7 \%$ & $8.7 \%$ & $8.7 \%$ & 2.5 & 1.23 \\
up and lay off & & & & & & & \\
scaffolding in \\
/outside the language \\
classroom.
\end{tabular}

\subsection{Question-2: To what extent are they aware of scaffolding in teaching?}

Whereas the statements in Table 1 are predominantly purported to measure the general theoretical knowledge of scaffolding, the ones in Table 2 cater for more pedagogically practical aspects of the participants' perceptions of scaffolding. It is noteworthy that a glance at the responses in this table would immediately unveil the participants' stronger confidence in the way they conceive this pedagogical facet of scaffolding which is significant in its own right. This is apparent in the particularly higher percentage of those who strongly agreed with the statements here than in Table 1 .

Although a possible reason for this comfort would be that participants are often more at home with more practical pedagogy than learning theory, it also reflects a general underlying problematic issue with the way EFL instructors understand and relate practice to theory. There appears to be a cultural trend among the EFL community to disregard or neglect to see the importance of the fact that theory per se can illuminate experience and hone practical skills.

It is also striking that there are apparently steady small percentages of those who agree or strongly disagree with the statements in Table 2 with a mode of $4.3 \%$ matching with disagree and $8.7 \%$ with strongly disagree respectively. Not less striking is the fact when none of the participants expressed disagreement with $(0 \%$ said they disagree with the statement "I believe scaffolding is useful for EFL classrooms"), $8.7 \%$ said they strongly disagree with it. In fact, the $8.7 \%$ runs as the statistical mode or pattern for all the responses in this table.

Table 2. Teachers' Beliefs and Perceptions

\begin{tabular}{llllllll}
\hline Item & $\begin{array}{l}\text { Strongly } \\
\text { Agree }\end{array}$ & Agree & Neutral & Disagree & $\begin{array}{l}\text { Strong } \\
\text { Disagree }\end{array}$ & Mean & SD \\
\hline $\begin{array}{l}\text { I believe scaffolding is } \\
\text { useful for EFL } \\
\text { classrooms. }\end{array}$ & $43.5 \%$ & $34.8 \%$ & $13 \%$ & $0 \%$ & $8.7 \%$ & 1.9 & 1.18 \\
\hline $\begin{array}{l}\text { I enjoy scaffolding } \\
\text { EFL learners. }\end{array}$ & 43.5 & $30.4 \%$ & $17.4 \%$ & $4.3 \%$ & $4.3 \%$ & 2.0 & 1.20 \\
\hline $\begin{array}{l}\text { I think EFL teachers } \\
\text { must be trained in }\end{array}$ & $39.1 \%$ & $26.1 \%$ & $21.7 \%$ & $4.3 \%$ & $8.7 \%$ & 2.2 & 1.34 \\
scaffolding. & & & & & & & \\
\hline $\begin{array}{l}\text { Scaffolds help students } \\
\text { build on prior } \\
\text { knowledge and }\end{array}$ & $30.4 \%$ & $43.5 \%$ & $8.7 \%$ & $8.7 \%$ & $8.7 \%$ & 2.3 & 1.39 \\
$\begin{array}{l}\text { internalize new } \\
\text { information. }\end{array}$ & & & & & & & \\
\hline $\begin{array}{l}\text { I think scaffolding's } \\
\text { ultimate goal is } \\
\text { learners' autonomy } \\
\text { and independence. }\end{array}$ & $26.1 \%$ & $34.8 \%$ & $26.1 \%$ & $4.3 \%$ & $8.7 \%$ & 2.3 & 1.26 \\
\hline
\end{tabular}




\subsubsection{Question-3: What is their attitude for practicing scaffolding in a pedagogical context?}

While the responses in Table 2 embark gradually into a bit more practical teaching aspect of the participants' scaffolding mental set and frames, Table 3 provides an even more profound insight in this respect as it explores this pedagogical paradigm deeper and much more comprehensively. It investigates the extent to which participants think they prepare, plan, allocate sufficient time for and the way they evaluate the impact of their scaffolding on learning outcomes.

They seem to also be largely positive and more confident like in Table 2 with most agreeing or strongly disagreeing with the statements. However, it is notable that the percentages of "strongly agrees" are lower than their counterparts in Table 2, whilst the "agrees" percentages in Table 3 appear much higher than the ones in Table 2. The" neutrals" are likewise relatively higher than their Table 2 counterparts. A possible interpretation for this difference, is that the questions are more specific requiring more classroom-oriented answers and hence more pedagogically insightful. Consequently, once faced with issues of having to provide conscious effort to scaffold their learner's such preparations, plans, timelines, catering for individual learners, etc., they get less and less confident, and, as a result, more and more conscious of the shortcomings and gaps in the required scaffolding effort.

Overall, the responses in Table 3 (as is also the case in Tables 1 and 2) seem to display a positive awareness of the significance of practicing scaffolding in a pedagogical context (real classroom contexts). Notwithstanding this, they look a bit reserved in their answers when it comes to more detailed responses; which delineate a more underlying problem with what is really going in the classrooms concerning providing the needed level and amount of scaffolding. The aim of this study as shown earlier in the article is to primarily explore the cognitive states of EFL instructors concerning scaffolding, an already gap in the literature, and the findings are interesting in their practical pedagogical implications, as will also be explored and emphasized later.

Table 3. Practices

\begin{tabular}{llllllll}
\hline Item & $\begin{array}{l}\text { Strongly } \\
\text { Agree }\end{array}$ & Agree & Neutral & Disagree & $\begin{array}{l}\text { Strong } \\
\text { Disagree }\end{array}$ & Mean & SD \\
\hline $\begin{array}{l}\text { I use scaffolding } \\
\text { strategies in EFL } \\
\text { classrooms. }\end{array}$ & $13 \%$ & $47.8 \%$ & $26.1 \%$ & $8.7 \%$ & $4.3 \%$ & 2.5 & 1.16 \\
\hline $\begin{array}{l}\text { I prepare more } \\
\text { scaffolds for the } \\
\text { beginners or false } \\
\text { beginners or low- }\end{array}$ & $13 \%$ & $47.8 \%$ & $34.8 \%$ & $4.3 \%$ & $13 \%$ & 2.3 & 0.88 \\
achievers. & & & & & & & \\
\hline $\begin{array}{l}\text { I gradually lay off } \\
\text { scaffolding to make } \\
\text { learners independent. }\end{array}$ & $17.4 \%$ & $43.5 \%$ & $34.8 \%$ & $0 \%$ & $4.3 \%$ & 2.3 & 0.92 \\
\hline $\begin{array}{l}\text { I employ an } \\
\text { appropriate amount of } \\
\text { scaffolding for each } \\
\text { learner. }\end{array}$ & $8.7 \%$ & $43.5 \%$ & $39.1 \%$ & $8.7 \%$ & $0 \%$ & 2.6 & 0.99 \\
\hline $\begin{array}{l}\text { My use of scaffolding } \\
\text { leads to better } \\
\text { learning outcomes. }\end{array}$ & $17.4 \%$ & $43.5 \%$ & $30.4 \%$ & $0 \%$ & $8.7 \%$ & 2.4 & 1.07 \\
\hline
\end{tabular}




\subsection{Focus Group Discussion (FGD)}

Focus Groups have increasingly proved to be of enormous benefit for research in the social sciences. This has taken the momentum from the growing awareness of the complexities of many research issues in a variety of fields. Being fully open to this fact, the present study sought to utilize FGD.

As already mentioned, periodical interactional seminars were held regularly in the English Department as part of a continuous professional development plan. Two of these seminars specifically focused on Scaffolding EFL learners. The post-seminar discussions were used as a research tool for thematic analysis in FGD drawing on Braun and Clarke (2008). The first theme that emerged out of interactional discourse related to Vygotsky's ZPD and Bakhtin's philosophy of dialogism, and trickled into sub-themes involving the sociocultural theory of learning, the gap between existing knowledge and further learning, and the dialogic nature of human consciousness and interactionism. The dialogic nature of the human mind has always been stressed by Habermas $(1984,1998)$ in what he calls Communicative Rationality. As the focus discussions deepened, senior and more experienced faculty members appeared to be well conversant and have good knowledge of most of these approaches, but the less experienced and the more novice seemed to obviously lack this knowledge as is evident from the results of the first item in Table 1 , where $26 \%$ of the responses range between neutrality and strong disagreement. However, during the discussion, there was a consensus among the participants on the significance of theoretical knowledge and awareness that an EFL teacher must-have for a better implementation of scaffolding strategies. The second theme that emerged during the course of the discussion was the construction analogy for the delineation of the concept of scaffolding in language teacher and language learning. The rationale behind this analogy was explained in detail by the senior faculty members and it was motivating for the rest of the participants to see how it works in education. After taking cognizance of theoretical and philosophical dimensions, the discussion trickled into a more pragmatic and practical mode. "Raising appropriate scaffolds and laying them off at the right time is very crucial while teaching EFL learners", remarked one participant. An expert in linguistics caught this opportunity to relate to Krashen's Affective Filter which aims at removing the obstacles in the way of the learning process. At the same time, another teacher came up with the "Input (i+1)" concept inducing a challenge in whatever support you build up while scaffolding EFL learners. Finally, it was thrashed out that the ultimate goal of scaffolding is to transport the learner to a stage where she or he could learn without any support - autonomous learning. All the participants agreed that avoiding spoon-feeding is a big challenge for the EFL teachers, and aligning the process with 21st-century skills, it is crucial for every EFL teacher to have a clear and pragmatic knowledge about scaffolding.

During the course of these fascinating focused discussions, it was clear to us that an increasingly conducive and supporting atmosphere for active learning was building up among the participants (in itself showcasing how scaffolding works, by the very people who are supposed to be scaffolding their students). Such an atmosphere is reminiscent of the very concepts and methods that underscore the process of scaffolding and which are constantly being emphasized throughout this study: Bakhtin's Dialogism, Vygotsky's ZPD, and Habermas's Communicative Rationality. Relevantly and interestingly, Barnawi (2016) has explored the role of negotiating pedagogies in improving student's writing in the context of Saudi Engineering college students. Drawing on Bakhtin's Dialogism and employing a teacher-research method in which teachers reflect critically on their own pedagogical strategies as well as their students learning practices, Barnawi has concluded that negotiating with his students their writing problems and providing them with spaces to voice up their own concerns and to reflect on instructional strategies, has significantly benefited both himself and his students. 
Table 4 illustrates the themes and sub-themes that came to the fore in the focus group discussions (FGD).

Table 4. Thematic Analysis in FGD

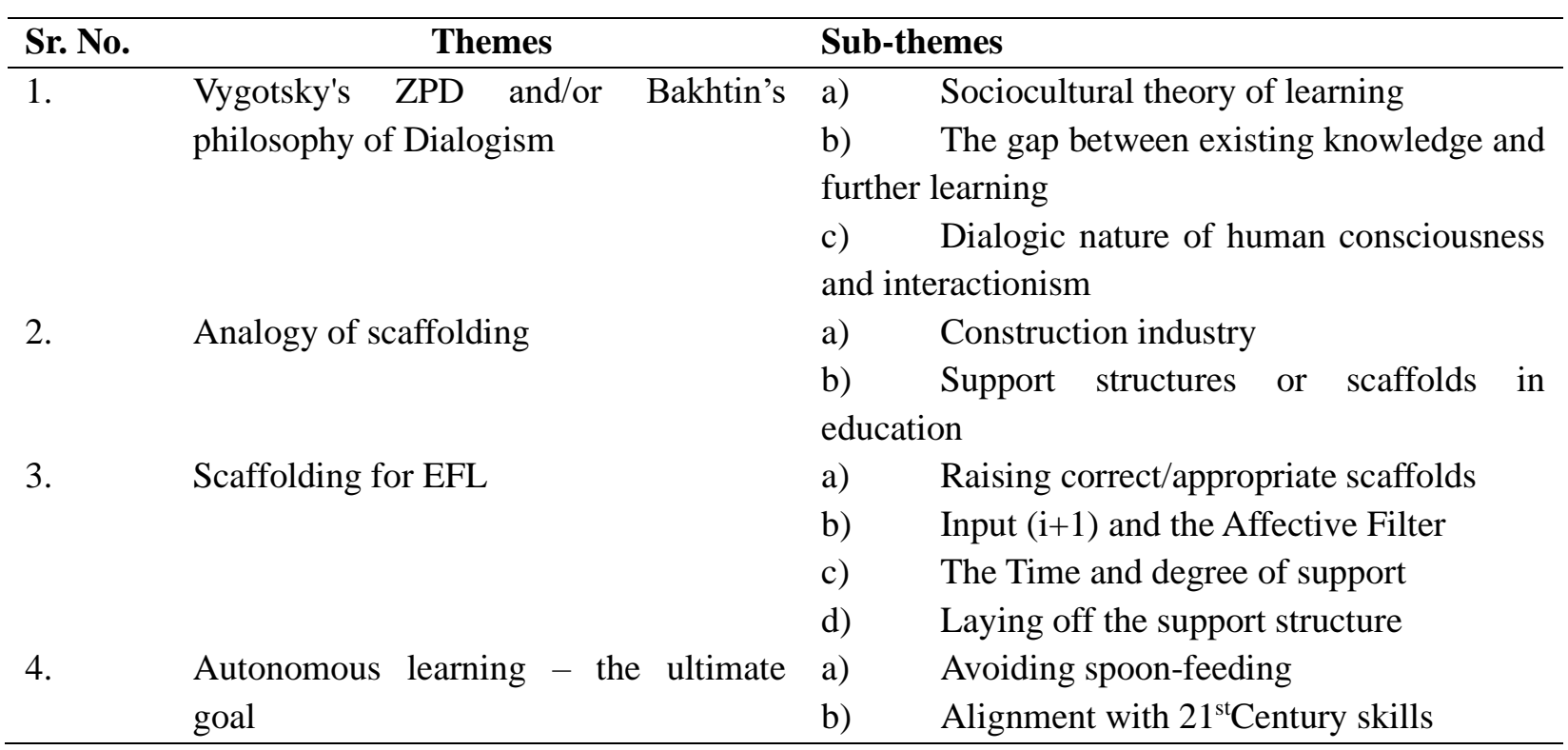

\section{Concluding Remarks}

Scaffolding in the contexts of EFL, being complex and multifaceted, has been under investigation for decades resulting in findings with interesting theoretical and pedagogical implications. Nevertheless, many aspects of scaffolding remain largely unexplored. Among these, the attitudes and cognitive states of EFL instructors would seem to stick out. This study is an attempt to fill this gap in the literature on scaffolding which will open up new ways of problematizing the issue. To this end, a group of $23 \mathrm{EFL}$ instructors of Majmaah University encompassing both genders and of different cultural backgrounds was explored for their attitudes and cognition of scaffolding theory and practice draws, to a greater or lesser degree, on their own experiences. Data collected via questionnaires and Focus Group Discussions (FGD) and analyzed afterward through relevant SPSS, reveal a set of interesting things. Instructors express generally positive attitudes towards scaffolding and perhaps assume that they often do scaffold their students. However, they appear more reserved when it comes to the practical aspects of scaffolding; looking more self-aware of the reality of the situation. In addition, and although they regard themselves as having a good theoretical background of scaffolding, many do not appear to possess adequate knowledge of some of the key theoretical underpinnings that informed the issue such as Vygotsky's ZPD and Bakhtin's Dialogism. Lack of knowledge on the part of a teacher might be perceived as undesirably embarrassing, particularly in the context of this study (Arabic-Islamic culture). However, all types of surveys appear prone to this, which is why an in-depth analysis is often imperative. This is usually also the case in analyzing Focus Group Discussion (FGD) data which this study has made use of, too.

Importantly, the overall study suggests that scaffolding is needed for achieving meaningful learning particularly in contexts where rote learning is deep-seated and difficult to uproot. It does so, by helping learners connect previous knowledge with new information and use it to solve new problems in new situations (an important aspect of meaningful learning). 
Novice EFL teachers need comprehensive training for identifying, selecting, and implementing scaffolding techniques and strategies. Particularly so, as applied linguists tend to align their effort with the $21^{\text {st }}$-century learning paradigm and skills.

Scaffolding needs to be incorporated, not only in teaching strategies but also in aspects of course design and materials preparation including documents such as course specifications and course reports. In addition, in an environment where quality and accreditation play a key role in education, innovative sets of scaffolds are required to commensurate with emerging trends and technologies.

Finally, the study suggests that further research is needed on some still less seen parts of the problem: students' attitudes and perceptions of scaffolding, the interrelationships (or intersectionality/transversality as more recent terms, for that matter) of teaching, learning and testing in scaffolding, the further problematization of scaffolding such as deepening its epistemological aspects and viewing it as a form of translanguaging along with the need for much more use of the qualitative methods of introspection and FGD in the field of language learning, in general, and scaffolding, in particular. Further research seek should new and innovative qualitative ways to fathom the cognitive, emotional, and ethical dimensions of the process of scaffolding, and thus contributing to the theory of learning, in general, and more specifically to the theory of language learning.

\subsection{Limitations and Delimitations}

Various factors contributed to limiting the findings of this study. First of all, this study investigated the attitudes and perceptions of applied linguists and EFL instructors and did not include the students' which would have probably made its findings much better and more generalizable. Second, the scope was limited to attitudes and perceptions, which contributed to limiting it, in many ways, (something that characterizes attitudes studies, anyway). However, it was also intended to fill a gap in the literature considering the vastness of the literature of other paradigms. Third, the novelty of the use of FGD in the context of the study may have impeded the maximum utilization of this powerful tool. Finally, the study has also been limited in one way or another by the fact that "The main challenge in scaffolding research appears to be its measurement", as insightfully put by van de Pol, Volman, Oort \& Beishuizen (2010:271).

\section{Statement}

This study has not been funded by any institute or organisation, there is no conflict of any interest and the data has taken several years to be gathered and processed.

\section{References}

Aguilar, F. A. R. (2020). What Impact Does Scaffolding Have on Level-1 Students Learning English as a Second Language? (Doctoral dissertation, Greensboro College).

Ahmadi Safa, M., \& Rozati, F. (2017). The impact of scaffolding and non scaffolding strategies on the EFL learners' listening comprehension development. The Journal of Educational Research, 110(5), 447-456.

Azir, I. D. A. (2019). Applying Peer Scaffolding to Enhance the EFL Vocational Students' Speaking Skills. Ethical Lingua: Journal of Language Teaching and Literature, 6(2), 149-157.

Barnawi, O. Z. (2016). The effect of negotiating pedagogies in Saudi college EFL writing classrooms. Language and Literacy, 18(1), 1-22. 
Braun, V., \& Clarke, V. (2008). Using thematic analysis in psychology. Qualitative research in psychology, 3(2), 77-101.

Caillaud, S., \& Flick, U. (2017). Focus groups in triangulation contexts. In A New Era in Focus Group Research (pp. 155-177). Palgrave Macmillan, London.

Charttrakul, K. (2009). Teaching English for young learners: a perspective view from Thai teacher. Thailand TESOL New Focus, 12-15.

Creswell, J. W., \& Clark, V. L. P. (2007). Designing and conducting mixed methods research. Thousand Oaks, CA: Sage Publications.

De Guerrero, M. C., \&Villamil, O. S. (2000). Activating the ZPD: Mutual scaffolding in L2 peer revision. The Modern Language Journal, 84(1), 51-68.

De Pol, Janneke van, \& Volman, Monique \& Beishuizen, Jos. (2010). Scaffolding in Teacher-Student Interaction: A Decade of Research. EducPsychol Rev (2010) 22:271-296 DOI 10.1007/s10648010-9127-6.

Donato, R. (1994). Collective scaffolding in second language learning. Vygotskian approaches to second language research, 33456.

Gunawardena, M. (2019). PEDAGOGIES FOR SCAFFOLDING THINKING IN ESL. Thinking Skills and Creativity in Second Language Education: Case Studies from International Perspectives, 42.

Habermas, Jurgen. (1984). The Theory of Communicative Action. Vol. I: Reason and the Rationalization of Society, T. McCarthy (trans.). Boston: Beacon. [German, 1981, vol. 1]

Habermas, Jurgen. (1998). On the Pragmatics of Communication, M. Cooke (ed.) Cambridge, MA: MIT Press.

Hammond, J., \& Gibbons, P. (2005). Putting scaffolding to work: The contribution of scaffolding in articulating ESL education.

Khamwan, T. (2007). The effects of interactional strategy training on teacher-student interaction in an EFL classroom (Unpublished master thesis). Nakhon Ratchasima, Suranaree University of Technology.

Leung, L. (2015). Validity, reliability, and generalizability in qualitative research. Journal of Family Medicine and Primary Care, 4(3), 324.

Li, D., \& Zhang, L. (2020). Exploring teacher scaffolding in a CLIL-framed EFL intensive reading class: A classroom discourse analysis approach. Language Teaching Research, 1362168820903340 .

Mansouri, S., \& Mashhadi Heidar, D. (2019). Peer/teacher technology-enhanced scaffolding through process approach and Iranian EFL learners' vocabulary knowledge: A probe into selfregulation. Journal of Teaching Language Skills, 38(3), 189-223.

Mohammed, M. F. (2020). Scaffolding with Online Tasks for Developing Critical Writing Skills of 2 nd Year Secondary School Students. Journal of Education, 76.

Nasr, M., Bagheri, M. S., Sadighi, F., \&Rassaei, E. (2018). Iranian EFL teachers' perceptions of assessment for learning regarding monitoring and scaffolding practices as a function of their demographics. Cogent Education, 5(1), 1558916.

Nomnian, S. (2002). Constructivism: Theory and its application to language teaching. Studies in Language and Language Teaching, 11, 62-71. 
Ohta, A. S. (2001). Second language acquisition processes in the classroom: Learning Japanese. Routledge.

Pathan, H., Memon, R. A., Memon, S., Khoso, A. R., \& Bux, I. (2018). A critical review of Vygotsky's sociocultural theory in second language acquisition. International Journal of English Linguistics, 8(4), 232.

Piaget, J. (1979). Comments on Vygotsky's critical remarks. Archives de Psychologie, 47(183), 237249.

Purnomo, A., \& Yuyun, I. (2019). EFL CLASSROOM AND LEARNER'S PERCEPTION ON DIRECT TRANSMISSION SCAFFOLDING. LLT Journal: A Journal on Language and Language Teaching, 22(1), 98-110.

Rababah, L., \& Almwajeh, M. (2018). Promoting creativity in EFL/ESL writing through scaffolding strategy. International Journal of English and Education, 7(3), 148-160.

Rachmajanti, S., Sulistyo, G. H., \&Suharyadi, A. N. (2019). Developing ELT Teachers Professionally towards Capability Scaffolding Roles: Reflecting on Their Standing SWOT. ICLI 2018, 351.

Rezaee, A. A., Khomeijani Farahani, A. A., \& Abdulameer Mubarak, L. (2018). Scaffolding and EFL Learners' Use of Language Learning Strategies in the Iraqi Language Teaching Context. Teaching the English Language, 12(2), 89-116.

SM Abdelshaheed, B. (2019). Using Instructional Scaffolding Strategies to Support Oral Productive Language Skills among English Majors at Majmaah University. Arab World English Journal (AWEJ) Volume, 10.

Taghizadeh, M., \& Saadatju, S. (2020). Engineering students' needs for listening scaffolding strategies and their perceptions of instructors' performance in an academic listening course. Research in Science \& Technological Education, 1-25.

Tajeddin, Z., \& Kamali, J. (2020). Typology of scaffolding in teacher discourse: Large data-based evidence from second language classrooms. International Journal of Applied Linguistics, 30(2), 329-343.

Teo, P. (2019). Teaching for the 21st century: A case for dialogic pedagogy. Learning, Culture and Social Interaction, 21, 170-178.

Troudi, S., \& Maazoun Zayani, E. (2020). Scaffolding EFL teachers' black box: towards a theoretical framework of EFL teachers' reading knowledge.

van de Pol, J., Volman, M., Oort, F., \& Beishuizen, J. (2015). The effects of scaffolding in the classroom: support contingency and student independent working time in relation to student achievement, task effort and appreciation of support. Instructional Science, 43(5), 615-641.

Vygotsky, L. S. (1987). Thinking and speech. The collected works of LS Vygotsky, 1, 39-285

Yu, G. (2004). Perception, practice, and progress: Significance of scaffolding and zone of proximal development for second or foreign language teachers. Asian EFL Journal, 6(4), 1-24.

\section{AUTHOR BIODATA}

Abdelmagid Abdelrahman Awadelkarim is an Assistant Professor at Majmaah University, College of Education (Department of Education), Saudi Arabia. He teaches both theoretical and applied linguistics, EFL, Discourse Analysis, Sociolinguistics, Pragmatics, Syntax, Morphology and Literary Criticism at Majm'ah 
university. He has taught English and linguistics at several universities in Sudan and Saudi Arabia. A published journalist, poet, essayist and literary critic with research interests spanning discourse analysis, interdisciplinarity, critical linguistics, socio-pragmatics, language learning strategies, critical teaching, language and identity/identities, interlanguage, intertextuality, lanuaging/translanguaging, new trends in language education ( postmethod, alternative instruction and assessment strategies, etc.), linguistics and literary criticism. He has participated in a number of international conferences(e.g. the International Annual conference in Language Learning in London-Brighton, 2013, 2014, Dubai 208, etc.) and has published in a variety of international and regional journals and is a member of some regional and international academic associations such as the International Ecolinguistics Association. 